\title{
LEARNING FOR GENDER EQUALITY IN POST- INDUSTRIAL ECONOMY: AN ONLINE PROGRAM OVERVIEW
}

\author{
Svetlana Usca \\ Rezekne Academy of Technologies, Latvia \\ Olena Mykhailenko \\ West Ukrainian National University, Ukraine \\ Anda Abuze \\ Rezekne Academy of Technologies, Latvia \\ Olga Vindaca \\ Rezekne Academy of Technologies, Latvia \\ Oksana Desyatnyuk \\ West Ukrainian National University, Ukraine
}

\begin{abstract}
The Latvian - Ukrainian project "Gender aspects of digital readiness and development of human capital in region" Nr.LV-UA/2018/3 focuses on the digitalization of education for closing the gender employment gap in the profoundly transforming labour market.

The article focuses on the online program "Learning for Gender Equality in Post-Industrial Economy" for professional development of educators. The program grounds on research previously done at the project. In this article, we review the program content and provide an evaluation of its participants.
\end{abstract}

Keywords: collaborative online program, digitalization, gender equality, digital empowerment, labour market.

\section{Introduction}

Rezekne Academy of Technology, Latvia, in cooperation with West Ukrainian National University, Ukraine conducted the Latvian-Ukrainian Cooperation Program project "Gender aspects of digital readiness and development of human capital in region" Nr.LV-UA/2018/3.

The program grounds on research previously done at the project Gender aspects of digital readiness and development of human capital in regions. The goal was based on the analysis of the digital readiness of university lecturers and students and the cultural and psychological factors of gender inequalities in the technological field, develop / implement a joint online teacher / teacher professional development program to reduce the gender disproportion of gender in the regions. The project includes seminars and video conferences and one of 
project results is Prepared Professional Development Program "Learning for Postindustrial Development" for International Learning in English Online, based on the Community Practice Model, with a view to further implementation of the Ukrainian and Latvian pedagogical activities.

The concept of this program is the following. Today, when education is rapidly digitalizing, is a great moment to create solutions for closing the gender employment gap at the profoundly digitalizing labour market. The Covid 19 pandemic sharpened the problem by increasing unemployment and accelerating digitalization. This made females' economic participation highly vulnerable because their presence in the technologically enriched working places is significantly lower than that of men. At the same time, both Latvia and Ukraine experience a shortage of IT specialists, and fastly growing IT companies increasingly become more flexible in working time and place and interested in hiring women. Education should nudge women-students to actively use this opportunity.

Stage 1 of this research confirmed higher anxiety and lower interest of women in learning about IT than their colleagues-men, in both national groups. So, the aim of the course is to rethink the existing teaching and learning practices for achieving the goal to increase the positive attitudes of women (both students and teachers) toward IT and overcome traditional biases about "female" and "nonfemale" occupations.

The goal of the course program is to provide teachers, educators, and students with a methodology of practical classes on women involvement in economic processes in regions. The goal of the paper: to conduct the overview and to analyze the compliance of educators' professional development online program "Learning for Gender Equality in Post-Industrial Economy" with the needs of program participants: teachers, educators and students from Latvia and Ukraine.

\section{Content Description of Educators' Professional Development Online Program "Learning for Gender Equality in Post-Industrial Economy"}

At the end of 2020, the approbation of the developed online program took place. The goal of the online program was to provide teachers, educators, and students with a methodology of practical classes on women involvement in economic processes in regions.

The online program consisted of 4 modules: The labour market transformation, women and the future of work, women and IT and gender gap reproduces in education (Figure 1). 


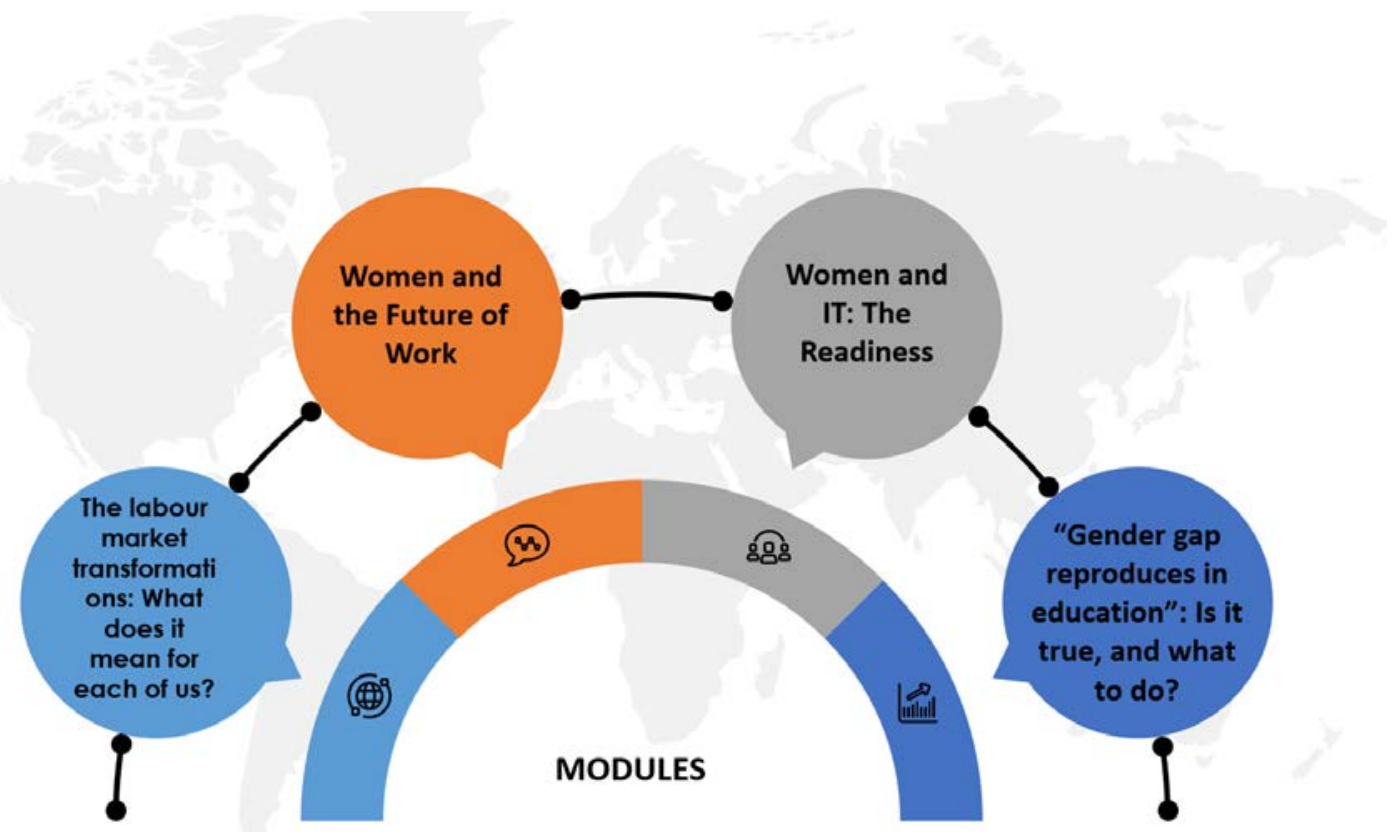

Figure 14 modules of online program

Module 1:

The labour market transformations: What does it mean for each of us?

Facilitated by PhD Econ. Olena Mykhailenko (Ukraine, Canada).

The Module covered teaching and learning in the digitalization age, reexamination of education, collaborative- constructivist (active) learning vs knowledge transmitting (passive) learning and Community of Inquire Model. Additionally, looked at social, economic and political factors in Latvia and Ukraine that affect the labor market. The issues and opportunities of human capital development, and the proactive role of universities to improve women's involvement and participation in economic processes. The Module I included the discussion of the labor market transformations and covered the five key aspects that are necessary to know about the future of job highlighted by World economic forum. These are the following: 1 . automation, robotization and digitalization of different industries, covering robot revolution; 2. new positive outlook, global large companies, including jobs landscape in 2022; 3. the division of labor between humans, machines and algorithms; 4. new tasks require new skills development, what is declining and what is growing; 5. lifelong learning (Stefanova Ratcheva, Leopold, 2018).

Alongside with this, the second discussion was based on technology attitudes of university students from Latvian and Ukraine from a gender perspective. As gender -oriented career decisions might be conditioned with a complex set of psychological and socio-cultural factors, so deep research is required, especially addressing in education programs (Mykhailenko et al., 2020). 
Learning for Gender Equality in Post-Industrial Economy:

an Online Program Overview

Additionally, the group work of participants was organized, based on Community of Inquiry Model practical application.

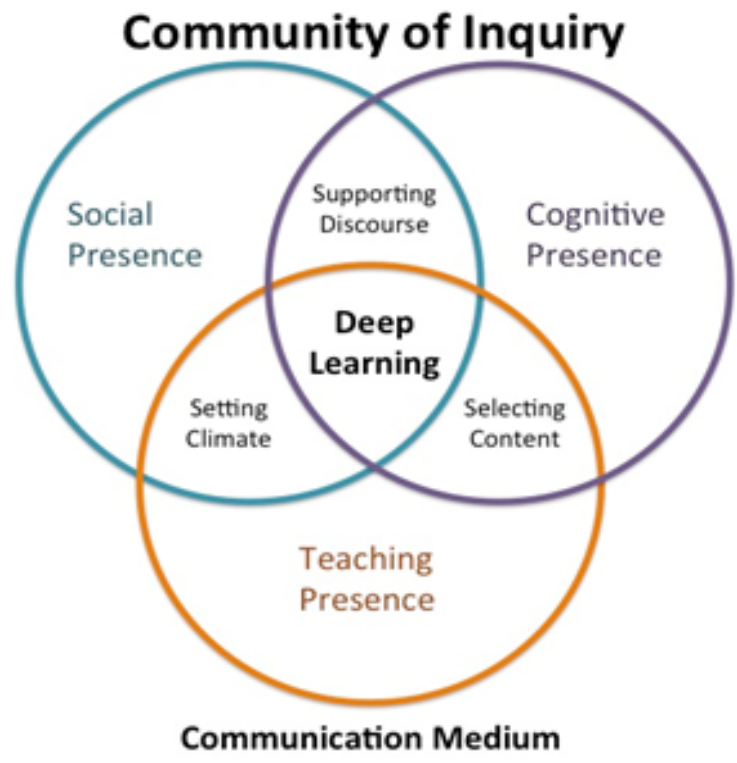

Figure 2 Elements of Educational Experience (Garrison, Akyol, 2013)

According to Fig.2 the deep learning that is also described as education experience is formed by three key elements cognitive, social and teaching presence. For better understanding, the categories and indicators for each element have been described (table 1).

Table 1 Key Elements of Community of Inquiry (Garrison, 2009)

\begin{tabular}{|l|l|l|}
\hline \multirow{4}{*}{ Element } & \multicolumn{1}{|c|}{ Category } & \multicolumn{1}{c|}{ Indicators } \\
\hline \multirow{4}{*}{$\begin{array}{l}\text { Cognitive } \\
\text { Presence }\end{array}$} & 1. Triggering Event & Sense of puzzlement \\
\cline { 2 - 3 } & 2. Exploration & Information exchange \\
\cline { 2 - 3 } & 3. Integration & Connecting ideas \\
\cline { 2 - 3 } & 4. Resolution & Applying new ideas \\
\hline \multirow{4}{*}{$\begin{array}{l}\text { Pocial } \\
\text { Tesence }\end{array}$} & 5. Emotional Expression & $\begin{array}{l}\text { Expression of emotions, use of humor, } \\
\text { self-disclosure }\end{array}$ \\
\cline { 2 - 3 } Presence & 6. Open communication & Continuing a thread, quoting from others \\
\cline { 2 - 3 } & 7. Group Cohesion & Encouraging collaboration \\
\cline { 2 - 3 } & 9. Instructional Management & Defining and initiating discussion topics \\
\cline { 2 - 3 } & 10. Direct Instruction & Focusing discussion \\
\hline
\end{tabular}


The participants of online program were divided into groups in order to make the mini-projects, basing on the offered Community of Inquire Model to the solution creation for teaching and learning in the digitalized age. The described activity helped to examine the learning procedure from cognitive, social and teaching aspects, especially indicating Covid-19 pandemic as triggering event for present digitalization of the world, including the educational field, focusing on women and IT perspective.

\section{Module 2: Women and the Future of Work}

Facilitated by Dr. Phil. Gilberto Marzano (Italy)

The Module 2 consists of two topics - 'Technology and changes in the labor market: the impact on women' and 'Women and Information and Communication Technologies'. Technology is opening new unbelievable perspectives. Information and communication technology (ICT) has spread worldwide penetrating into the contemporary life from defense and industry, to business, hospitals, education and entertainment. Overall, digital technologies are bringing about huge changes and will increasingly condition participation in society. The online session included the presentation covering the opportunities for women in the future world of work, despite the significantly lower technology participation rates of women in comparison with men (Marzano, Lubkina, 2019).

The offered discussion included the following aspect - automation: the need of bridging skills gaps: (a) digital skills (b) entrepreneurship, (c) stress management, (d) risk management.

Module 3:

\section{Women and IT: Digital Readiness}

Facilitated by PhD Econ. Olena Mykhailenko (Ukraine, Canada)

This Module offered the answer to the question: What does digital readiness mean? The presentation highlighted the economic and cultural portraits of Latvia and Ukraine and the key findings of the conducted project "Gender aspects of digital readiness and development of human capital in region" and the discussion about the J. Peterson's interview, a famous Canadian psychologist, professor at the University of Toronto, regarding the crises of masculinity.

\section{Module 4:}

“Gender Gap Reproduces in Education": Is it True, and What to Do? Facilitated by Dr.habil.paed. Irena Zogla (Latvia)

The online session of this module required special preparation, including the acquaintance of three models of education: rights, capabilities and human capital (Robeyns, 2006), curriculum transformation through educator and student attitude 
Learning for Gender Equality in Post-Industrial Economy:

an Online Program Overview

development to digital competence (Žogla, Ušča, Kijaško, 2019) and preparation for work in Industry 4,0, the readiness of worker (Blayone, van Oostveen, 2021). The digital readiness model was analyzed, including the five readiness perspectives: interpersonal, flexibility, innovation, inter-agent and technological. The participants were divided into groups to work out the elements and indicators of each digital readiness model perspective by presenting the results using Jamboard.

\section{The Evaluation of Educators' Professional Development Online Program "Learning for Gender Equality in Post-Industrial Economy"}

The final project of the online program included the creation of Digital Readiness Model and filling in the SWOT analyses for each participant. For results analyses the surveys of 40 participants were used.

Summing up, the participants of online program emphasized the high level of organization and successful cross cultural, cross border collaboration in online environment. The analysis of the project participants' feedback highlighted several positive aspects of the program (Fig.3).

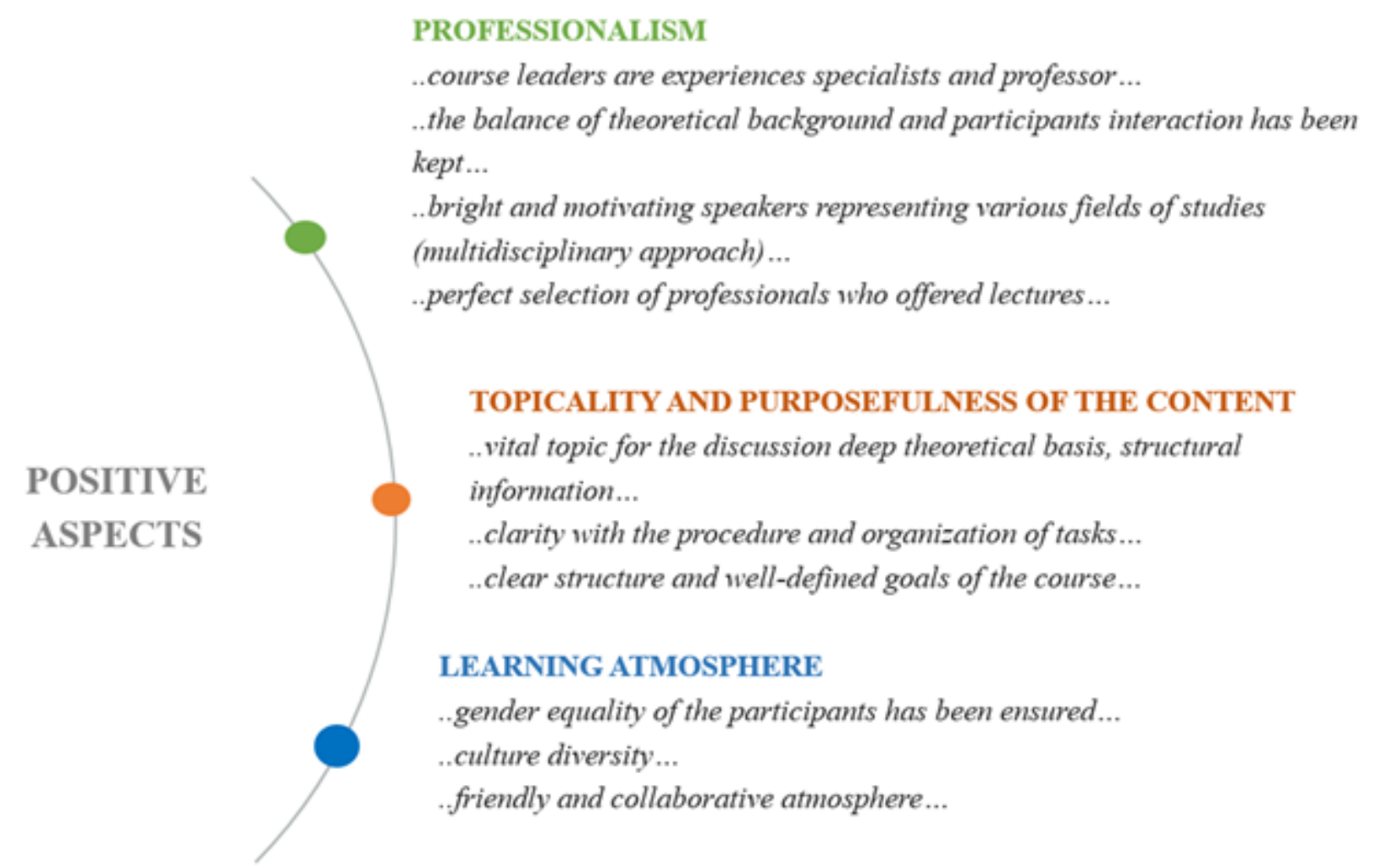

Figure 3. Positive aspects of the program, according to the participants' feedback 
By generating participant-response profiles during the online program approbation two notable aspects were actualized for further program improvement:

1) more methodological support is needed (.. insufficient number of best practice examples...);

2) time distribution (.. lack of time to cover all the issues in question...); the programme may take longer time to implement.

Participants were also quite self-critical, indicating that they should be more active. We believe that the manifestations of the activity could have been influenced by the different experiences of participants, both in relation to the topic of the courses and the activities in the e-environment. In addition, the programme was run simultaneously in two countries, and workshops and communication were in English. Language skills could be an important barrier to involvement in discussions.

All participants had an assighments to elaborate their personal professional development plans. The sample of those is presented below (Table 2).

\section{Table 2 An example of personal professional development plans submitted by the participants}

\begin{tabular}{|l|l|l|}
\hline & \multicolumn{1}{|c|}{ TEACHING PRACTICES } & \multicolumn{1}{c|}{ LEARNING PRACTICES } \\
\hline $\begin{array}{l}\text { CURRENT } \\
\text { SITUATION }\end{array}$ & $\begin{array}{l}\text { Institutional and professional } \\
\text { support and incentives for } \\
\text { adopting technologies needed. }\end{array}$ & $\begin{array}{l}\text { Variety of educational resources, } \\
\text { but with different quality of } \\
\text { materials and the access } \\
\text { opportunities. }\end{array}$ \\
\hline GOAL(S) & $\begin{array}{l}\text { To have interoperability between } \\
\text { different IT platforms and } \\
\text { technologies to support } \\
\text { integration of profile Digital } \\
\text { Teaching components }\end{array}$ & $\begin{array}{l}\text { To develop and provide Digital } \\
\text { Learning solutions which (1) } \\
\text { integrates both synchronous and } \\
\text { asynchronous learning, and (2) to } \\
\text { be a perspective tools that foster } \\
\text { collaboration among learners. }\end{array}$ \\
\hline SKILLS GAP & $\begin{array}{l}\text { Adopting IT technologies in } \\
\text { Digital teaching has its } \\
\text { challenges, as it can be both } \\
\text { difficult and time-consuming. }\end{array}$ & $\begin{array}{l}\text { The risks of the so-called “cognitive } \\
\text { load", with individual's processing } \\
\text { demands exceed his/her } \\
\text { processing capabilities, appears. }\end{array}$ \\
\hline ACTIONS & $\begin{array}{l}\text { To include different digital } \\
\text { components (e.g., films/movies, } \\
\text { e-books, cartoons) into Digital } \\
\text { teaching practices }\end{array}$ & $\begin{array}{l}\text { To bring the profile audience the } \\
\text { content really needed, addressing } \\
\text { the design, development, and } \\
\text { impact of IT technology on } \\
\text { workplace learning and training. }\end{array}$ \\
\hline EVALUATION & $\begin{array}{l}\text { To develop teaching/learning analytics as a profile research field and a } \\
\text { part of institutional and professional support }\end{array}$ \\
\hline
\end{tabular}


Learning for Gender Equality in Post-Industrial Economy:

an Online Program Overview

Summarizing the courses, participants emphasize that "The courses created opportunities for further collaboration on this topic and future partnerships" and "The courses have offered an opportunity to engage in deep thinking about the Industry 4.0 and 5.0 reality on how to prepare ourselves as educators and our students for it."

\section{Conclusions}

The offered activity - educators' professional development online program "Learning for Gender Equality in Post-Industrial Economy", under the Latvian Ukrainian project "Gender aspects of digital readiness and development of human capital in region" Nr.LV-UA/2018/3, was 72 hours long, including four Modules with 16 hours synchronous online sessions and 56 hours autonomous learning for teachers, educators and students with a methodology of practical classes on women's involvement in economic process in regions. It provided the theoretical background and practical usage in the four key fields: the labor market transformation; teaching and learning in digitalization age; women and the future of work; women and IT, readiness; gender gap reproduces in education.

The content of the online program was analyzed and re-examined through the surveys of the participants, including SWOT analyses. Based on the general evaluation of the program the following positive aspects were highlighted: topicality and relevance of the content, high professional level of speakers, positive learning atmosphere in online environment. While the key limitations were the following: cross-cultural aspect, time limitation, language barrier. The offered 72 hours was not enough for the detailed analyses and discussion of the topic as well as active practical experience.

The project promoted cross-cultural understanding, exchange of experience on methodology and organization of research in both countries, international and interregional scientific and pedagogical networking, awareness of teachers of a number of universities in Ukraine and Latvia with innovative digital learning models and practices, which is especially important in the forced transition to online learning through the COVID crisis, the involvement of educators in international research and publications, improving the quality of project management in both participating institutions.

\section{Acknowledgement}

This article was supported by the Latvia - Ukraine Joint Cooperation programme project "Gender aspects of digital readiness and development of human capital in region” Project Nr.LV-UA/2020/4 


\section{References}

Blayone, T. \& van Oostveen, R. (2021). Prepared for work in Industry 4.0? Modelling the target activity system and five dimensions of worker readiness. International Journal of Computer Integrated Manufacturing, 34(1), 1-19.

DOI:https://doi.org/10.1080/0951192X.2020.1836677

Blayone, T. J., Mykhailenko, O., Usca, S., Abuze, A., Romanets, I., \& Oleksiiv, M. (2020). Exploring technology attitudes and personal-cultural orientations as student readiness factors for digitalised work. Higher Education, Skills and Work-Based Learning. DOI: https://doi.org/10.1108/HESWBL-03-2020-0041

Blayone, T., van Oostveen, R., Barber, W., DiGiuseppe, M., \& Childs, E. (2017). Democratizing digital learning: Theorizing the Fully Online Learning Community model. International Journal of Educational Technology in Higher Education, 14(13), 1-16. DOI: https://doi.org/10.1186/s41239-017-0051-4

Blayone, T., Mykhailenko, O., van Oostveen, R., \& Barber, W. (2017). Ready for digital learning? A mixed-methods exploration of surveyed technology competencies and authentic performance activity. Education and Information Technologies, 23(3), 13771402. DOI: https://doi.org/10.1007/s10639-017-9662-6

Garrison, D.R. (2009). Communities of Inquiry in Online Learning. Canada: Universiy of Calgary. DOI: 10.4018/978-1-60566-198-8.ch052

Garrison, D.R. \& Akyol, Z. (2013). The Community of Inquiry Theoretical Framework. Retrieved from https://www.researchgate.net/publication/284306348_The_ Community_of_Inquiry_Theoretical_Framework

Marzano, G. \& Lubkina, V. (2019). The Digital Gender Divide: an Overview. Society. Integration. Education. Proceedings of International Scientific conference, Volume V, 413-421. DOI: 10.17770/sie2019vol5.3849

Mykhailenko, O. et al. (2020). Optimism, interest and opportunity: Comparing attitudes of university students in Latvia and Ukraine toward IT learning and work. Compare: A Journal of Comparative and International Education. doi:https://doi.org/10.1080/ 03057925.2020.1843999

Mykhailenko, O., Blayone, T.J.B., Usca, S., Kvasovskii, O., \& Desyatnik, O. (2020). Optimism, interest and opportunity: Comparing attitudes of university students in Latvia and Ukraine toward IT learning and work. Compare. A Journal of Comparative and International Education. DOI: https://doi.org/10.1080/03057925.2020

Robeyns, I. (2006). Three models of education: Rights, capabilities and human capital. Theory and Research in Education 4(1). DOI: https://doi.org/10.1177/1477878506060683

Stefanova Ratcheva, V. \& Leopold, T. (2018). 5 things to know about the future of jobs. World Economic Forum. Retrieved from https://www.weforum.org/agenda/2018/09/future-ofjobs-2018-things-to-know/

Žogla, I., Ušča, S., \& Kijaško, M. (2019). Focus on Curriculum Transformation Through Educator and Student Attitude Development to Digital Competence. ATEE Spring Conference Proceedings Innovation, Technologies and Research in Education, 82-99. DOI: https://doi.org/10.22364/atee.2019.itre 
